\title{
KERATIN HYDROLYSATES EXTRACTED FROM SHEEP WOOL WITH POTENTIAL USE AS OR- GANIC FERTILIZER
}

\author{
Mariana Daniela BERECHET ${ }^{1 *}$, Demetra SIMION ${ }^{1}$, Maria STANCA ${ }^{1}$, Cosmin-Andrei ALEXE $^{1}$, \\ Ciprian CHELARU ${ }^{1}$, Maria RÂPĂ ${ }^{2}$ \\ ${ }^{1}$ INCDTP - Division: Leather and Footwear Research Institute, 031215 Bucharest, Romania, \\ marianadanielaberechet@yahoo.co.uk; demetra.simion@yahoo.com; maria.stanca@icpi.ro; \\ cosminandrei.alexe@yahoo.com; ciprian.chelaru@icpi.ro \\ 2Politehnica University of Bucharest, 060042, Romania, rapa_m2002@yahoo.com
}

\section{KERATIN HYDROLYSATES EXTRACTED FROM SHEEP WOOL WITH POTENTIAL USE AS ORGANIC FERTILIZER}

ABSTRACT. Keratin hydrolysates were obtained from sheep wool by alkaline hydrolysis at different concentrations of $\mathrm{KOH}(3 \%, 5 \%$ and $8 \%)$ and temperatures $\left(75^{\circ} \mathrm{C}, 85^{\circ} \mathrm{C}, 95^{\circ} \mathrm{C}\right.$ and $\left.99^{\circ} \mathrm{C}\right)$ of the reaction medium. The protein content of the keratin extracts was between $65.54 \%$ and $87.10 \%$. Particle measurements showed a decrease in particle size with the increase of concentration and temperature of the reaction medium. The ATR-FTIR spectra revealed specific bands to proteins and sulfur originated from keratin amino acids. The keratin hydrolysate type $\mathrm{KerK}_{95}$ was further investigated as organic fertilizer for two types of wheat seeds. The results showed that the use of $5 \%$ KerK $8_{95}$ led to the increase of the wheat stems lengths by $10.7 \%$ for Mirastar wheat and $18.3 \%$ for Tamino wheat, respectively, compared to control sample. Keratin hydrolysates are promising biopolymers as organic fertilizers in agriculture applications.

KEY WORDS: keratin hydrolysates, protein substance, organic fertilizer

HIDROLIZATE DE CHERATINĂ EXTRASE DIN LÂNĂ DE OAIE CU POTENȚIAL DE UTILIZARE CA FERTILIZATOR ORGANIC

REZUMAT. Hidrolizele de cheratină au fost obținute din lână de oaie prin hidroliză alcalină la diferite concentrații de $\mathrm{KOH}(3 \%, 5 \%$ și $8 \%)$ și temperaturi $\left(75^{\circ} \mathrm{C}, 85^{\circ} \mathrm{C}, 95^{\circ} \mathrm{C}\right.$ ș $\left.99^{\circ} \mathrm{C}\right)$ ale mediului de reacție. Caracteristicile fizico-chimice ale cheratinelor au arătat valori ale substanței proteice între $65,54 \%$ și $87,10 \%$. Măsurătorile mărimii particulelor au indicat o scădere a dimensiunii particulelor odată cu creșterea concentrației și cu creșterea temperaturii mediului de reacție. Spectrele ATR-FTIR au prezentat benzi spectrale specifice proteinelor și compușilor cu sulf proveniți de la aminoacizii din cheratină. Hidrolizatul de cheratină KerK $8_{95}$ a fost utilizat ca fertilizant pentru două tipuri de semințe de grâu. S-a obținut o creștere a lungimii tulpinii grâului cu 10,7\% pentru soiul Mirastar și 18,3\% pentru soiul Tamino în cazul aplicării a $5 \% \mathrm{KerK}_{95}$, în comparație cu proba martor. Hidrolizatele de cheratină sunt biopolimeri cu potențial pentru utilizare ca fertilizanți organici cu aplicații în agricultură.

CUVINTE CHEIE: hidrolizate de cheratină, substanță proteică, fertilizant organic

HYDROLYSATS DE KÉRATINE EXTRAITS DE LA LAINE DE MOUTON AVEC UNE UTILISATION POTENTIELLE COMME ENGRAIS ORGANIQUE RÉSUMÉ. Les hydrolysats de kératine ont été obtenus à partir de la laine de mouton par hydrolyse alcaline à différentes concentrations à $3 \%$, $5 \%$ et $8 \%$ de $\mathrm{KOH}$ et à différentes températures à $75^{\circ} \mathrm{C}, 85^{\circ} \mathrm{C}, 95^{\circ} \mathrm{C}$ et $99^{\circ} \mathrm{C}$ du milieu réactionnel. Les caractéristiques physico-chimiques des kératines ont montré des valeurs de la substance protéique entre $65,54 \%$ et $87,10 \%$. Les mesures de la taille des particules ont montré une diminution de la taille des particules avec l'augmentation de la concentration et avec l'augmentation de la température du milieu réactionnel. Les spectres ATR-FTIR ont montré des bandes spectrales spécifiques aux protéines et aux composés soufrés de la kératine. L'hydrolysat de kératine KerK8 $8_{95}$ a été utilisé comme engrais pour deux types de blé. Une augmentation de la souche de blé a été obtenue de 10,7\% pour le blé Mirastar et de 18,3\% pour le blé Tamino lorsque $5 \%$ de KerK $8_{95}$ ont été appliqués, par rapport à l'échantillon témoin. Les hydrolysats de kératine sont des biopolymères susceptibles d'être utilisés comme engrais organique en agriculture.

MOTS CLÉS : hydrolysats de kératine, substance protéique, fertilisant organique

\section{INTRODUCTION}

Wool keratin has a distinct threedimensional structure and contains approximately $95 \%$ protein, $0.5 \%$ minerals, $5 \%$ lipids [1-3]. This structure of keratin consists (protein fibers: $50.5 \mathrm{wt} \% \mathrm{C}, 22.0 \mathrm{wt} \% \mathrm{O}, 16.5$ wt $\% \mathrm{~N}, 6.8 \mathrm{wt} \% \mathrm{H}, 3.7 \% \mathrm{~S}$, and $0.5 \mathrm{wt} \%$ ash) of 2 polypeptide chains composed of different amino acids, connected with inter and intramolecular bonds [2]. Disulfide, hydrogen and ionic bonds are characteristic for the keratin structure and these lead to its stability and strength increase, and resistance to dissolution in various solvents $[4,5]$. Keratins are insoluble in most solvents such as organic solvents, water, weak acids, alkaline solutions and enzymes, such as trypsin or pepsin. This biopolymer contains glycine, proline, serine and cysteine in high concentrations, while the lysine, methionine and histidine are found in a low content [6]. The ionic bonds between carboxylic anions and ammonium cations depend mainly on the $\mathrm{pH}$ and at the isoelectric point, at $\mathrm{pH}=4.9$, they are strong. These ionic bonds are weak in extreme conditions of acidity or alkalinity. At low pH values these bonds can

\footnotetext{
"Correspodence to: Mariana Daniela BERECHET, INCDTP - Division: Leather and Footwear Research Institute, 031215 Bucharest, Romania, marianadanielaberechet@yahoo.co.uk
} 
be reduced by the protonating of carboxylic group, while the deprotonating of amino group occurs at high $\mathrm{pH}$ levels [7]. The solubilization of the wool structure occurs mainly by disturbing the complex structure of keratin [8]. Commonly used methods for the solubilisation of keratin are: reduction [9], oxidation [10], alkaline extraction [11], microwave irradiation [12], steam treatment [13] and ionic liquids [14]. Various biomaterials containing keratin have been manufactured and researched for their application in the field of biomedical sciences in the form of hydrogels [15-17], films [18], fibers, sponges, scaffolds [19-20] and wound patches [24]. For these applications, keratin biomaterials have demonstrated biocompatibility [2527], unique chemical structure [28], and biodegradability [29-31]. In addition, the cheap raw materials such as wool and hair are renewable resources of this biopolymer extraction [32, 33]. In a previous paper, we demonstrated the stimulating growth effect of new emulsions, based on collagen and keratin additives, on the Tamino and Mirastar wheat seeds [34]. The aim of this paper is to investigate the influence of different concentrations of $\mathrm{KOH}$ and temperatures conditions for the extraction of keratin hydrolysate from sheep wool, to analyze the physical-chemical properties of keratin extracts and the potential use of keratin extract as organic fertilizer for stimulating the growth of wheat plants. As compared to other reported research [35] we have used $\mathrm{KOH}$ as hydrolysis agent for its nutritional potential for plant growth.

\section{EXPERIMENTAL}

\section{Materials and Methods}

\section{Materials}

Potassium hydroxide (flakes $\mathrm{KOH}$ ) from Lachner, Neratovice, Czech Republic, ammonia solution $\left(\mathrm{NH}_{3} 25 \%\right)$, and anhydrous sodium carbonate $\left(\mathrm{Na}_{2} \mathrm{CO}_{3}\right)$ from Chimreactiv SRL, Bucharest were used in this experiment. Sheep wool was purchased from local sheep farmers.

\section{Extraction of Keratin Hydrolysates}

Keratin hydrolysates were obtained by alkaline hydrolysis with $\mathrm{KOH}$. First, the sheep wool was degreased in a solution of $1 \mathrm{~g} / \mathrm{L} \mathrm{NH}_{3}$ $25 \%, 1 \mathrm{~g} / \mathrm{L}$ anionic detergent and $1 \mathrm{~g} / \mathrm{L} \mathrm{Na}_{2} \mathrm{CO}_{3}$ by stirring for $6 \mathrm{~h}$ at $40^{\circ} \mathrm{C}$. After the wash process, the wool was dried in open space and then cut into small pieces (2-4 mm). Two series of keratins were obtained in varied conditions of temperature or concentration during the production process. One series of keratins was obtained at constant temperature of $99^{\circ} \mathrm{C}$ and with $3 \%\left(\right.$ KerK3 $\left._{99}\right), 5 \%\left(\right.$ KerK5 $\left._{99}\right)$ and $8 \%\left(\right.$ KerK8 $\left._{99}\right)$ $\mathrm{KOH}(\mathrm{w} / \mathrm{w})$. Second series of keratins was obtained at a constant concentration of $\mathrm{KOH} 8 \%$ $(\mathrm{w} / \mathrm{w})$ and three different temperatures, $75^{\circ} \mathrm{C}$ $\left(\right.$ KerK $\left._{75}\right), 85^{\circ} \mathrm{C}\left(\right.$ KerK8 $\left._{85}\right)$, and $95^{\circ} \mathrm{C}\left(\mathrm{KerK}_{95}\right)$. All alkaline extraction processes were performed under mechanical stirring for $3 \mathrm{~h}$.

\section{Characterization of Keratin Hydrolysates}

The physical-chemical characteristics of keratin hydrolysates were analyzed according to standardized and in-house methods: SR EN ISO 4684:2006 (dry matter), SR EN ISO 4047:2008 (ash content), SR ISO 5397:1996 (total nitrogen and protein). The size particles and Zeta potential of keratins were measured by Dynamic light scattering (DLS) technique with Zetasizer NanoZS device from Malvern (Malvern Hills, UK). The results of the analyses were expressed as the average values of three determinations.

\section{ATR-FTIR Spectroscopy}

ATR-FTIR analysis was performed with a FT-IR/ATR spectrometer - Jasco 4200 operating in the range of 4000 to $550 \mathrm{~cm}^{-1}$, with a spectral resolution of $0.5 \mathrm{~cm}^{-1}$. 
Wheat Seeds Treatment

Two concentrations of KerK $8_{95}, 3 \%$ and $5 \%(w / v)$ in water were applied to Tamino and Mirastar wheat seeds and the growth of stems was observed up to 10 days by measurement of stems' length and compared to control sample (treated with water).

\section{RESULTS AND DISCUSSIONS}

\section{Physical-Chemical Analyses}

The main physical-chemical characteristics of keratins hydrolysate extracts obtained with $3 \%, 5 \%$ and $8 \% \mathrm{KOH}$ and at constant temperature of $99^{\circ} \mathrm{C}$ are shown in Table 1.

Table 1: Physical-chemical characteristics of $\mathrm{KerK}_{99}, \mathrm{KerK}_{99}$ and KerK ${ }_{99}$ keratin hydrolysates

\begin{tabular}{lccc}
\hline Characteristics & KerK3 $_{99}$ & KerK5 $_{99}$ & KerK8 $_{99}$ \\
\hline Dry matter, \% & $1.71 \pm 0.02$ & $7.01 \pm 0.03$ & $7.17 \pm 0.04$ \\
Ash*, \% & $12.22 \pm 1.4$ & $11.41 \pm 1.8$ & $11.12 \pm 0.23$ \\
Total nitrogen*, \% & $12.86 \pm 2.45$ & $13.41 \pm 0.2$ & $14.12 \pm 0.45$ \\
Protein*, \% & $77.77 \pm 3.47$ & $81.31 \pm 0.46$ & $85.49 \pm 2.7$ \\
pH, units of pH & $9.49 \pm 0.58$ & $9.92 \pm 0.12$ & $10.05 \pm 0.68$ \\
\hline
\end{tabular}

* Values are reported at dry substance.

The main physico-chemical characteristic values of the keratins reported in Table 1 increased with the increase of the concentration of $\mathrm{KOH}$, from $3 \%$ to $5 \%$ and $8 \%$. Thus, the total nitrogen values increased from $12.86 \%$ in the case of $\mathrm{KerK}_{99}$ to $13.41 \%$ in $\mathrm{KerK}_{99}$ and to $14.12 \%$ in $\mathrm{KerK}_{99}$; also, the protein concentration increased from $77.77 \%$ in $\mathrm{KerK3}_{99}$, to $81.31 \%$ in KerK5 $_{99}$ and to $85.49 \%$ in $\mathrm{KerK}_{99}$, respectively (Table 1).

Table 2: Particle sizes, polydispersity and Zeta potential of KerK3 ${ }_{99}$, KerK5 ${ }_{99}$ and KerK $8_{99}$ keratin hydrolysates

\begin{tabular}{cccccccc}
\hline $\begin{array}{c}\text { Keratin } \\
\text { hydrolysate }\end{array}$ & \multicolumn{9}{c}{ Particle populations (\%) and size $(\mathrm{nm})$} & $\begin{array}{c}\text { Average } \\
\text { dimension, } \\
\text { nm }\end{array}$ & $\begin{array}{c}\text { Pdl } \\
\text { Majority population } 1\end{array}$ & \multicolumn{2}{c}{$\begin{array}{c}\text { Majority population 2 } \\
\text { Size }\end{array}$} & $\%$ & Size & $\%$ & $\begin{array}{c}\text { Zeta } \\
\text { potential, } \\
\mathrm{mV}\end{array}$ \\
\hline KerK3 $_{99}$ & 116.1 & 13.3 & 1024 & 86.7 & 892.9 & 0.668 & -22.3 \\
KerK5 $_{99}$ & 107.5 & 5.3 & 1401 & 94.7 & 1025 & 0.326 & -13.3 \\
KerK8 $_{99}$ & 70.35 & 5.2 & 1050 & 94.8 & 1256 & 0.377 & -13.7 \\
\hline
\end{tabular}

DLS analysis shows the appearance of small particle sizes from $116.1 \mathrm{~nm}$ in KerK3 ${ }_{99}$ to $107.5 \mathrm{~nm}$ in KerK5 ${ }_{99}$, and to $70.35 \mathrm{~nm}$ in KerK8 ${ }_{99^{\prime}}$ which decrease in size as the concentration of the extractive medium increases. The value

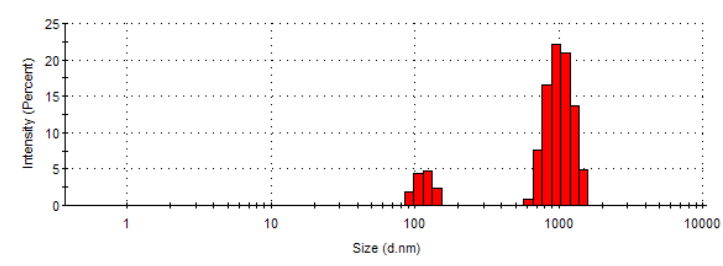

(a) of the Zeta potential is between $-22.3 \mathrm{mV}$ and -13.7 mV (Table 2, Figure 1) showing a decrease of their stability even the polydispersity values indicate more homogenous composition.

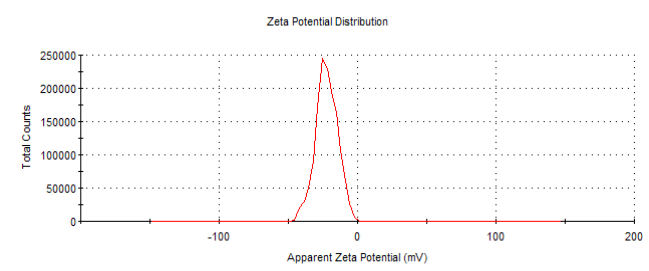

(b) 


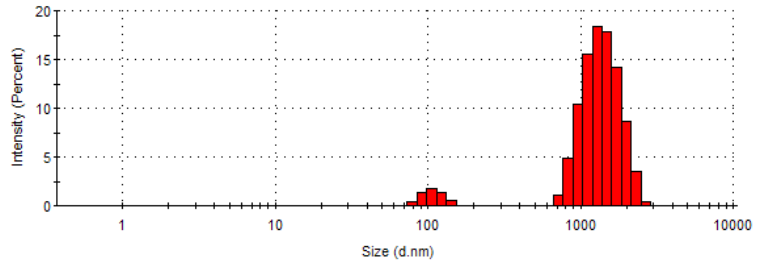

(c)

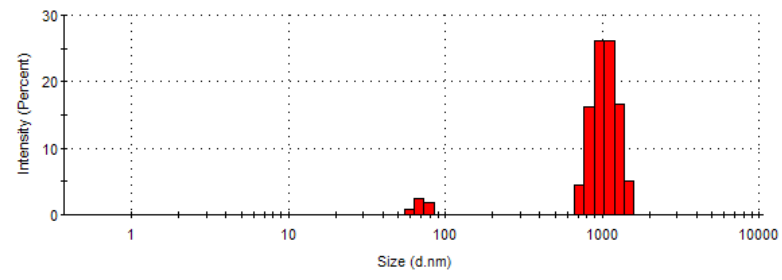

(e)

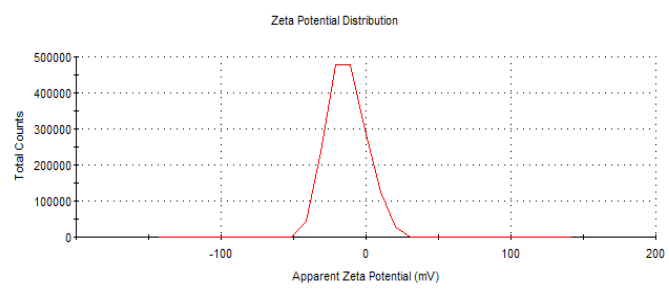

(d)

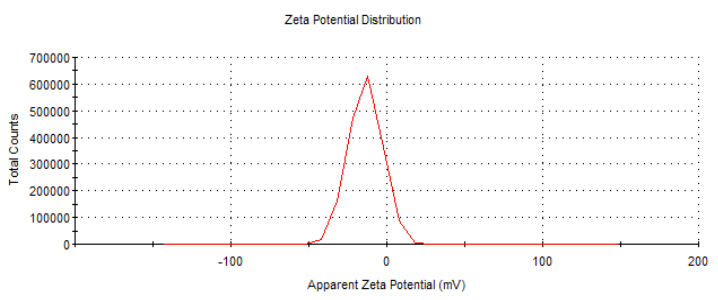

(f)

Figure 1. Histograms of particle size distribution and Zeta potential in $\operatorname{KerK3}_{99}(a, b), \operatorname{KerK5}_{99}(c, d)$, and KerK8 ${ }_{99}(e, f)$

Physical-chemical characteristics for the second series of keratin hydrolysate extracts

obtained at temperature of $75^{\circ} \mathrm{C}, 85^{\circ} \mathrm{C}, 95^{\circ} \mathrm{C}$ and a concentration of $8 \% \mathrm{KOH}$ are shown in Table 3.

Table 3: Physical-chemical characteristics of $\mathrm{KerK}_{75}, \mathrm{KerK}_{85}$ and KerK $8_{95}$ keratin hydrolysate extracts

\begin{tabular}{lccc}
\hline Characteristics & KerK8 $_{75}$ & KerK8 $_{85}$ & KerK8 $_{95}$ \\
\hline Dry matter, \% & $1.48 \pm 0.02$ & $2.64 \pm 0.1$ & $4.03 \pm 0.05$ \\
Ash*, \% & $17.75 \pm 2.4$ & $17.05 \pm 0.98$ & $12.16 \pm 1.42$ \\
Total nitrogen*, \% & $10.81 \pm 3.7$ & $13.64 \pm 1.21$ & $14.39 \pm 2.7$ \\
Protein*, \% & $65.54 \pm 2.6$ & $82.58 \pm 1.1$ & $87.10 \pm 5.04$ \\
pH, units of pH & $11.85 \pm 1.04$ & $11.19 \pm 0.20$ & $10.35 \pm 0.89$ \\
\hline
\end{tabular}

* Values are reported at dry substance.

The keratin extracts obtained at the concentration of $8 \% \mathrm{KOH}$ in the reaction medium and temperatures of $75^{\circ} \mathrm{C}, 85^{\circ} \mathrm{C}$ and $95^{\circ} \mathrm{C}$ are characterized by total nitrogen values that increase from $10.81 \%$ in KerK ${ }_{75}$, to $13.64 \%$ in $\mathrm{KerK}_{85}$ and to $14.39 \%$ in $\mathrm{KerK}_{95}$ and protein values increasing between $65.54 \%$ to $87.10 \%$ (Table 3).

Table 4: Particle sizes and Zeta potential of $\mathrm{KerK}_{75}, \mathrm{KerK}_{85}$ and $\mathrm{KerK} 8_{95}$ keratin hydrolysate

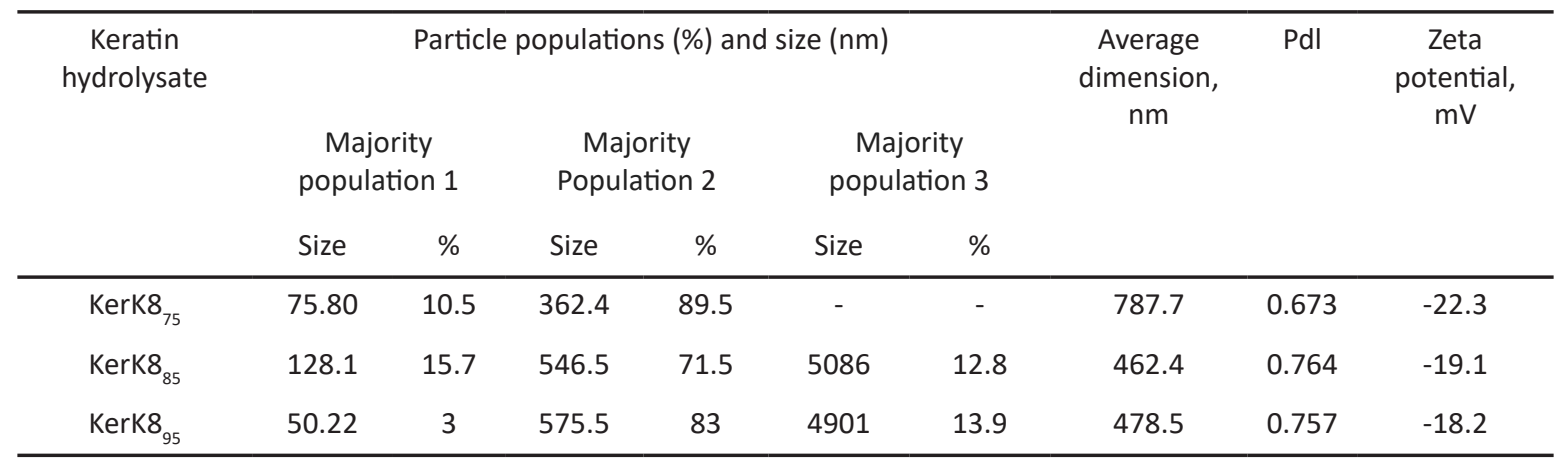


Particle size measurement for the KerK $8_{75}$ KerK $8_{85}$ and KerK $_{95}$ keratins shows dimensions between $50.22 \mathrm{~nm}$ and $128.1 \mathrm{~nm}$ for the first majority population, between $362.4 \mathrm{~nm}$ and $575.5 \mathrm{~nm}$ for the second majority population and between $4901 \mathrm{~nm}$ and $5086 \mathrm{~nm}$ for the third

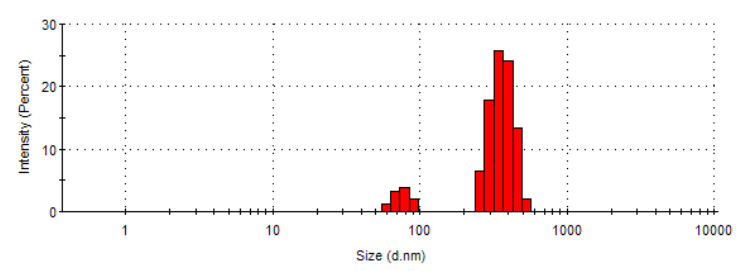

(a)

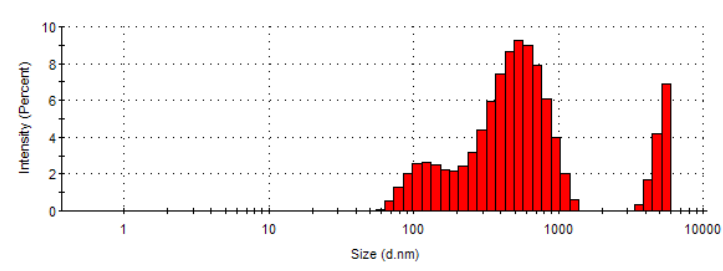

(c)

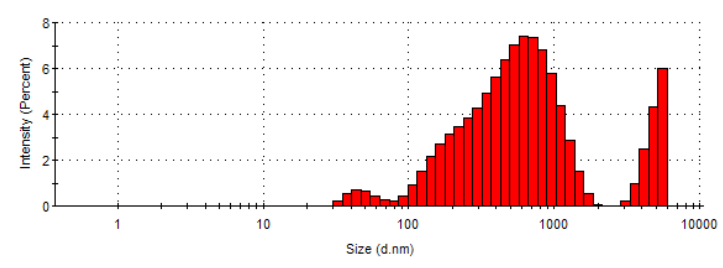

(e) majority population. Histograms of particle size distribution show an increase in the particle size spectrum with the increase in temperature of the hydrolysis process (Figure 2). The value of

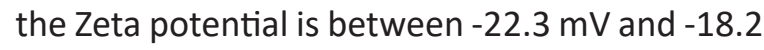
$\mathrm{mV}$ (Table 4, Figure 2).

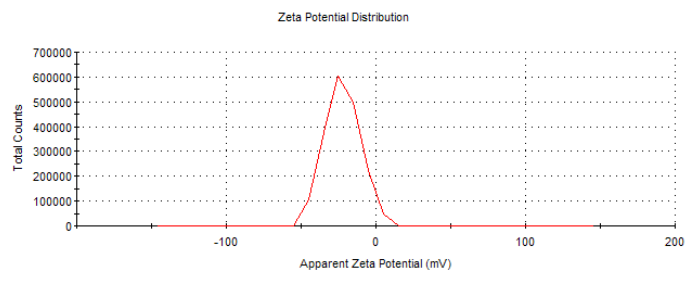

(b)

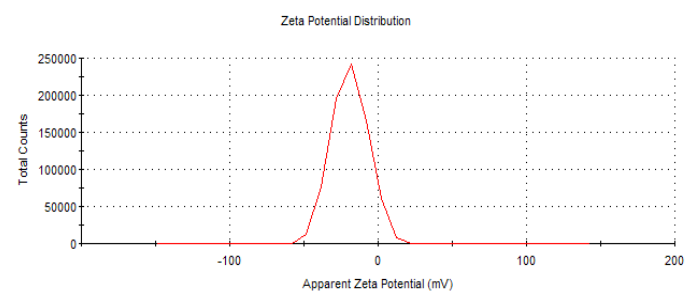

(d)

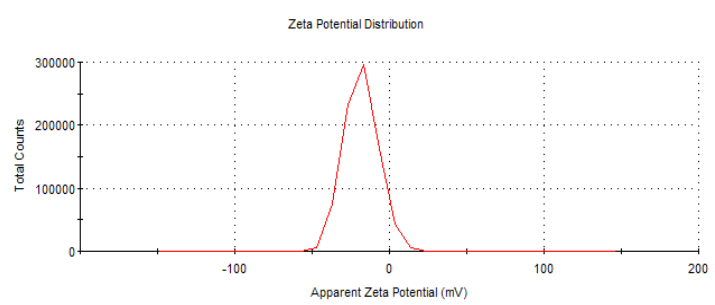

(f)

Figure 2. Histograms of particle size distribution and Zeta potential in $\operatorname{KerK}_{75}(a, b), \operatorname{KerK}_{85}(c, d)$, and $\operatorname{KerK}_{95}(\mathrm{e}, \mathrm{f})$

DLS analyses show that the process of hydrolysis with $8 \% \mathrm{KOH}$ at temperature between $75-95^{\circ} \mathrm{C}$, leads to more dispersed keratin hydrolysates with three majority populations and average size ranging between $787.7 \mathrm{~nm}$ and $462.4 \mathrm{~nm}$, lower than the series of keratin hydrolysates obtained at $99^{\circ} \mathrm{C}$ with $3-8 \% \mathrm{KOH}$, having an average size between 1256-892.9 nm.

\section{FT-IR Analyses}

Figure 3 represents the ATR-FTIR spectra of hydrolysated keratin at different concentrations of $\mathrm{KOH}$, while Figure 4 shows the ATR-FTIR spectra of hydrolysated keratin at different temperatures. 


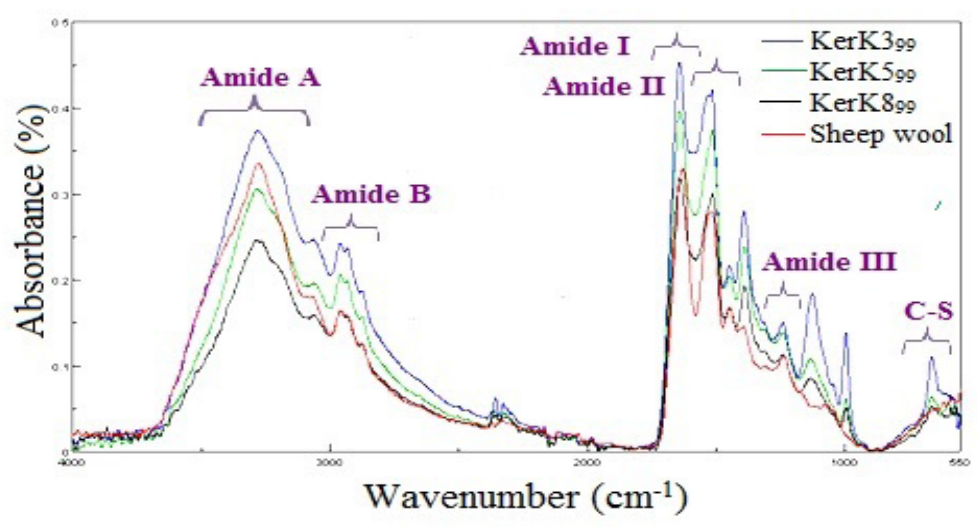

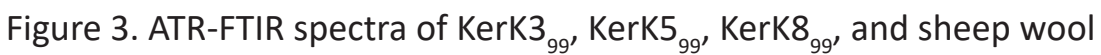

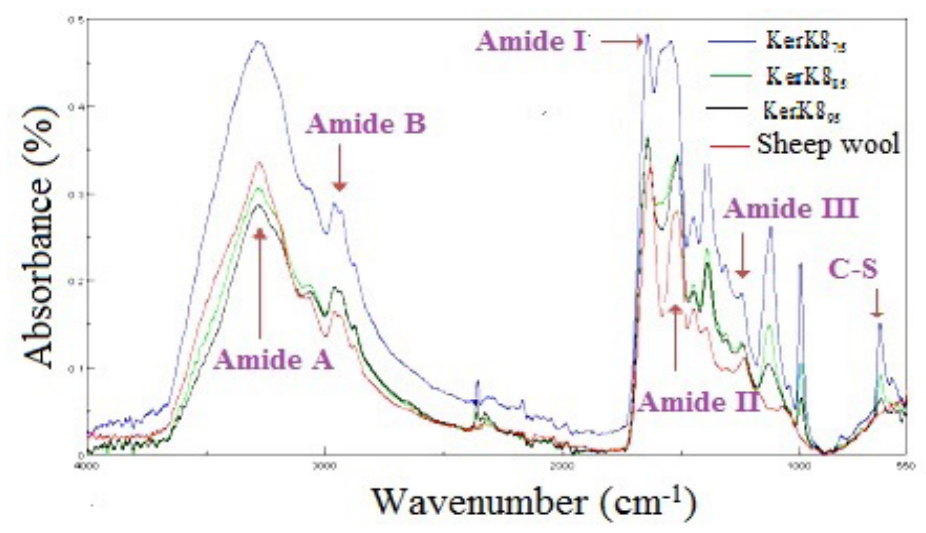

Figure 4. ATR-FTIR spectra of KerK $8_{75}, \mathrm{KerK}_{85}, \mathrm{KerK}_{95}$, and sheep wool

Keratin is easier to break into smaller peptide fragments after hydrolysis of S-S bonds between macromolecular chains [35-38]. The spectral band from $3282-3288 \mathrm{~cm}^{-1}$ can be attributed to the stretching vibration of $-\mathrm{O}-\mathrm{H}$ and $-\mathrm{N}-\mathrm{H}$ (Amide A) [39]. The absorption peak between $2960-2962 \mathrm{~cm}^{-1}$ is attributed to the asymmetric extent of $-\mathrm{CH}_{2}$ - (Amide B). The specific band from $1630-1643 \mathrm{~cm}^{-1}$ is assigned to the extension $-\mathrm{C}=\mathrm{O}$ (Amide I) [40-42]. The absorption peaks around $1515-1517 \mathrm{~cm}^{-1}$ and 1237-1245 $\mathrm{cm}^{-1}$ correspond to the $\mathrm{N}-\mathrm{H}$ band coupled to the $\mathrm{C}-\mathrm{H}$ (Amide II) range and the $\mathrm{C}-\mathrm{H}$ (Amide III) range, respectively. The absorption bands around $670 \mathrm{~cm}^{-1}$ and $578-541 \mathrm{~cm}^{-1}$ can be attributed to the extension of the C-S bond and the S-S bond, as well as to the deformation of the $\mathrm{C}-\mathrm{C}$ bond corresponding to keratin specific sulfur compounds [35, 43-46]. The ATR-FTIR spectra show higher intensities of the specific bands for keratin hydrolysate obtained with $8 \%$ $\mathrm{KOH}$ at $99^{\circ} \mathrm{C}$ and at $95^{\circ} \mathrm{C}$ (Figures 3 and 4), these also having the highest concentration of protein (Table 1).

\section{Bioactive Properties of Keratin Hydrolysate for Growth Stimulation of Wheat Plants}

Based on the results presented in Tables 1 and 3, the KerK8 ${ }_{95}$ shows the higher content of nitrogen (14.39\%) and relatively low particle size, compared to the other keratin extracts. For this reason, the KerK ${ }_{95}$ was selected as potential organic fertilizer to treat the Tamino and Mirastar wheat seeds and to monitor the plants growth over a 10-day period. The experiments were performed in laboratory conditions, as follows: 
25 seeds for each type of wheat were put in contact with control (without keratin, treated only with water), $3 \% \mathrm{KerK}_{95}$ and $5 \% \mathrm{KerK}_{95}$, respectively. The preliminary results obtained by measuring the wheat stem length from day 7 to day 10 are plotted in Figures 5 and 6.

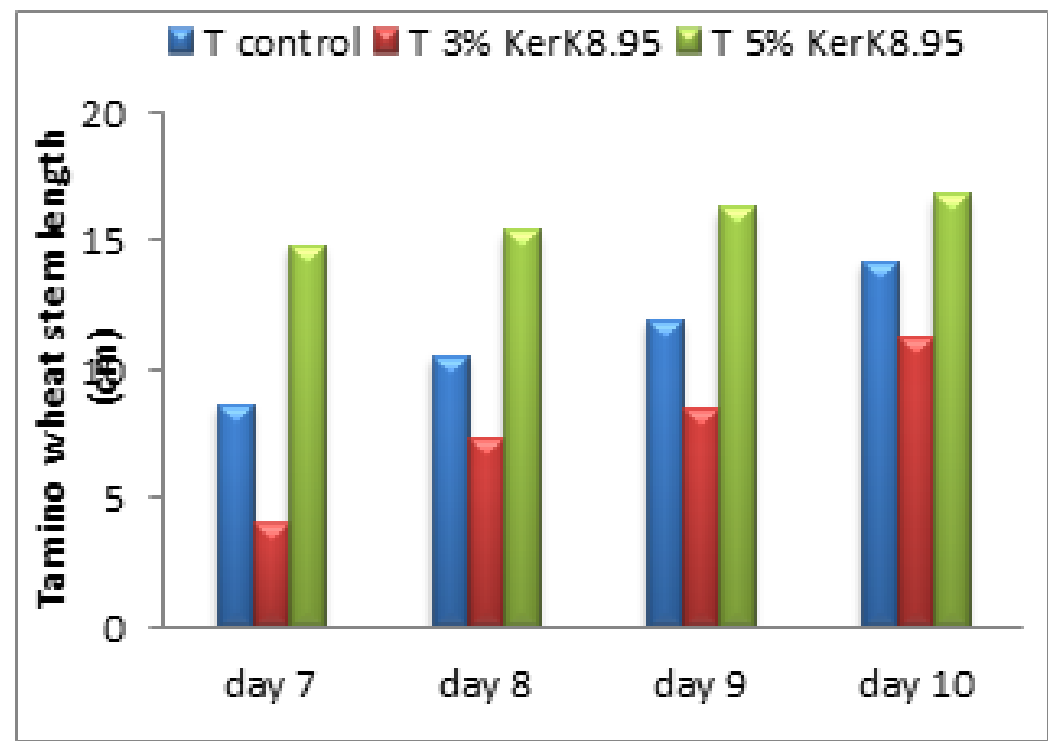

Figure 5. The effect of $\mathrm{KerK}_{95}$ on the increase in Tamino wheat stem length $(\mathrm{cm})$ compared to control

Figure 5 shows the growth of Tamino wheat stems treated with $3 \%$ and $5 \%$ KerK $_{95}$ during seven to ten days of the experiment. It is observed that the wheat seeds treated with $5 \% \mathrm{KerK}_{95}$ led to the higher increase, from $14.8 \mathrm{~cm}$ to $16.8 \mathrm{~cm}$, while in the case of Tamino wheat treated with $3 \% \mathrm{KerK}_{95}$, the increase was smaller, between $4 \mathrm{~cm}$ to $11.2 \mathrm{~cm}$. The seeds treated without keratin extract showed a stem development from $8.6 \mathrm{~cm}$ to $14.2 \mathrm{~cm}$. The keratin hydrolysate KerK ${ }_{95}$ was used in these experiments to stimulate the development of Tamino wheat stem, obtaining the highest increase with $18.3 \%$ in the case of the treatment with $5 \% \mathrm{KerK}_{95}$ compared to control sample.

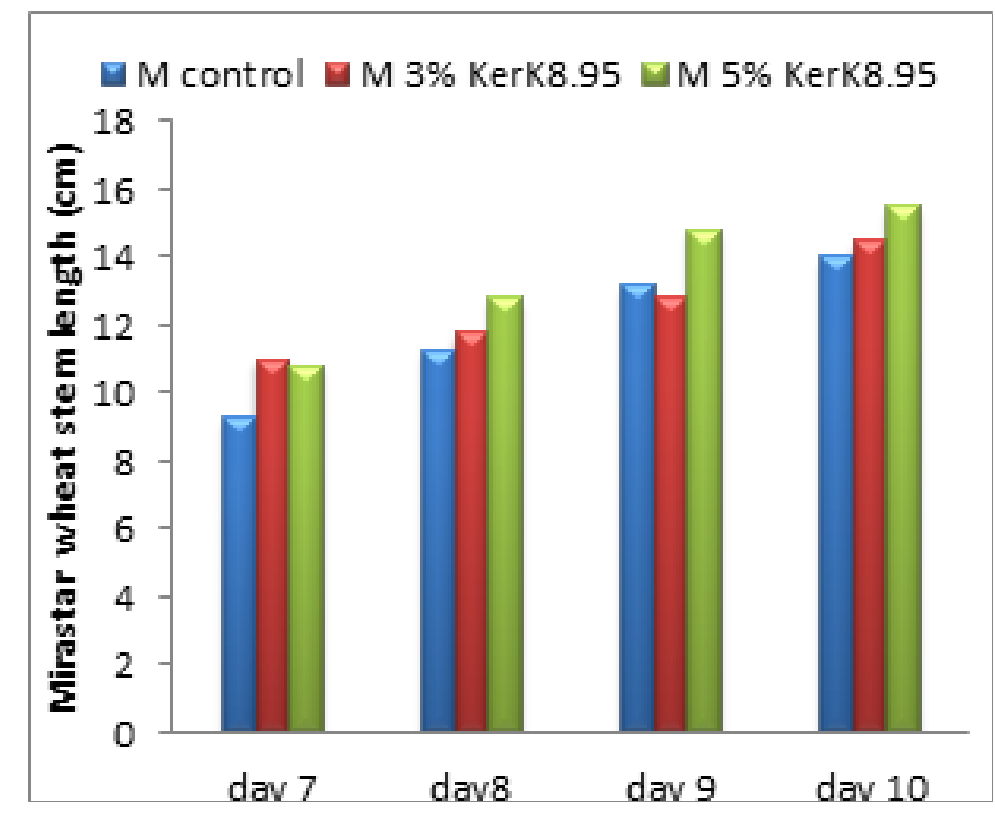

Figure 6. The effect of KerK $_{95}$ on the increase in Mirastar wheat stem length $(\mathrm{cm})$ compared to control 
Figure 6 shows the growth of Mirastar wheat seeds treated with $3 \%$ and $5 \% \mathrm{KerK}_{95}$ during seven to ten days of the experiment. It is observed that the Mirastar wheat seeds treated with $5 \% \mathrm{KerK}_{95}$ led to the higher increase, from $10.8 \mathrm{~cm}$ to $15.8 \mathrm{~cm}$, while in the case of seeds treated with $3 \% \mathrm{KerK}_{95}$, the increasewas between $11 \mathrm{~cm}$ to $14.5 \mathrm{~cm}$. The keratin hydrolysate $\mathrm{KerK}_{95}$ was used in these experiments to stimulate the development of Mirastar wheat stem, obtaining the highest increase with $10.7 \%$ in the case of $5 \% \mathrm{KerK}_{95}$ compared to control sample. However, all keratin extracts show nitrogen and sulfur in their structures, so they are likely to be used as potential organic fertilizer for plant growth stimulation. The next experiments will investigate in detail the influence of hydrolysed keratin on wheat seeds according to standardized procedure.

\section{CONCLUSIONS}

Keratin hydrolysates were obtained from sheep's wool by alkaline hydrolysis at different concentrations of $\mathrm{KOH}$, i.e. $3 \%, 5 \%$ and $8 \%$ and different temperatures, i.e. $75^{\circ} \mathrm{C}, 85^{\circ} \mathrm{C}, 95^{\circ} \mathrm{C}$ and $99^{\circ} \mathrm{C}$ of the reaction medium. The physicalchemical characteristics of the keratins show values of the protein substance between $65.54 \%$ and $87.10 \%$. Particle size measurements show a decrease in particle size with the increase of concentration and temperature of the reaction medium. ATR-FTIR analyses confirmed the protein structure with increased intensities for specific bands in the case of more concentrated keratin hydrolysates and with specific bands for sulfur originated from cysteine amino acid. The keratin hydrolysate coded $\mathrm{KerK}_{95}$ was used in preliminary experiments as organic fertilizer to facilitate the growth of two wheat types. The results showed an increase with $10.7 \%$ of stem length for Mirastar wheat and $18.3 \%$ in the case of Tamino wheat seeds treated with $5 \% \mathrm{KerK}_{95}$, compared to control sample. Results showed that the keratin hydrolysates obtained from sheep wool could be promising biomaterials for use as organic fertilizer in agriculture.

\section{Acknowledgements}

The research was carried out under project number 19 Nucleu/2019, PN 191701 02, CREATIV_PIEL, 4PERFORM-TEX-PEL project, funded by Romanian Ministry of Education and Research.

\section{REFERENCES}

1. Ayutthaya, S.I.N., Tanpichai, S., Wootthikanokkhan, J., Keratin extracted from chicken feather waste: extraction, preparation, and structural characterization of the keratin and keratin/ biopolymer films and electrospuns, I Polym Environ, 2015, 23, 4, 506-516, https://doi. org/10.1007/s10924-015-0725-8.

2. Aluigi, A., Tonetti, C., Rombaldoni, F., Puglia, D., Fortunati, E., Armentano, I., Santulli, C., Torre, L., Kenny, J.M., Keratins extracted from Merino wool and Brown Alpaca fibres as potential fillers for PLLA-based biocomposites, J Mater Sci, 2014, 49, 18, 6257-6269, https://doi.org/10.1007/s10853014-8350-9.

3. Wennstrom, H., Harris, C.P., The Recovery and Purification of Wool Fat, A Discussion of the Economic Possibility of an Important Raw Material, J Am Oil Chem Soc, 1927, 4, 353-356, https://doi.org/10.1007/BF02663006.

4. Park, M., Kim, B.-S., Shin, H.K., Park, S.-J., Kim, H.Y., Preparation and characterization of keratinbased biocomposite hydrogels prepared by electron beam irradiation, Mater Sci Eng C, 2013, 33, 8, 5051-5057, https://doi.org/10.1016/j. msec.2013.08.032.

5. Poole, A.J., Lyons, R.E., Church, J.S., Dissolving feather keratin using sodium sulfide for biopolymer applications, J Polym Environ, 2011, 19, 4, 995-1004, https://doi.org/10.1007/s10924011-0365-6.

6. Korniłłowicz-Kowalska, T., Bohacz, J., Biodegradation of keratin waste: theory and practical aspects, Waste Manag, 2011, 31, 8, 1689-1701, https://doi.org/10.1016/j. wasman.2011.03.024.

7. Tonin, C., Aluigi, A., Varesano, A., Vineis, C., Keratin-based nanofibres, Nanofibers, Ashok Kumar, IntechOpen, 2010, 139-158, https:// doi.org/10.5772/8151.

8. Wang, B., Yang, W., McKittrick, J., Meyers, M.A., Keratin: structure, mechanical properties, occurrence in biological organisms, and efforts at bioinspiration, Prog Mater Sci, 2016, 76, 229-318, https://doi.org/10.1016/j. pmatsci.2015.06.001.

9. Yamauchi, K., Yamauchi, A., Kusunoki, T., Kohda, A., Konishi, Y., Preparation of stable aqueous solution of keratins, and physiochemical and biodegradational 
properties of films, J Biomed Mater Res, 1996, 31, 4, 439-444, https://doi.org/10.1002/ (SICI)1097-4636(199608)31:4<439::AIDJBM1>3.0.CO;2-M.

10. Buchanan, J.H., A cystine-rich protein fraction from oxidized $\alpha$-keratin, Biochem J, 1977, 167, 2, 489-491, https://doi.org/10.1042/bj1670489.

11. Tsuda, Y., Nomura, Y., Properties of alkaline hydrolyzed water fowl feather keratin, Anim Sci J, 2014, 85, 2, 180-185, https://doi. org/10.1111/asj.12093.

12. Zoccola, M., Aluigi, A., Patrucco, A., Vineis, C., Forlini, F., Locatelli, P., Sacchi, M.C., Tonin, C., Microwave-assisted chemical-free hydrolysis of wool keratin, Text ResJ, 2012, 82, 19, 2006-2018, https://doi.org/10.1177/0040517512452948.

13. Tonin, C., Zoccola, M., Aluigi, A., Varesano, A., Montarsolo, A., Vineis, C., Zimbardi, F., Study on the conversion of wool keratin by steam explosion, Biomacromolecules, 2006, 7, 12, 3499-3504, https://doi.org/10.1021/ bm060597w.

14. Xie, H., Li, S., Zhang, S., lonic liquids as novel solvents for the dissolution and blending of wool keratin fibers, Green Chem, 2005, 7, 8, 606-608, https://doi.org/10.1039/b502547h.

15. Sierpinski, P., Garrett, J., Ma, J., Apel, P., Klorig, D., Smith, T., Koman, L.A., Atala, A., Van Dyke, M., The use of keratin biomaterials derived from human hair for the promotion of rapid regeneration of peripheral nerves, Biomaterials, 2008, 29, 1, 118-128, https://doi. org/10.1016/j.biomaterials.2007.08.023.

16. Lin, Y.-C., Ramadan, M., Van Dyke, M., Kokai, L.E., Philips, B.J., Rubin, J.P., Marra, K., Keratin gel filler for peripheral nervere pair in a rodent sciatic nerveinjury model, Plast Reconstr Surg, 2012, 129, 1, 67-78, https://doi.org/10.1097/ PRS.0b013e3182268ae0.

17. Apel, P.J., Garrett, J.P., Sierpinski, P., Ma, J., Atala, A., Smith, T.L., Koman, L.A., Van Dyke, M., Peripheral nerve regeneration using a keratin-based scaffold: long-term functional and histological outcomes in a mouse model, $J$ Hand Surg, 2008, 33, 9, 1541-1547, https://doi. org/10.1016/j.jhsa.2008.05.034.

18. Sharma, S., Gupta, A., Kumar, A., Kee, C.G., Kamyab, H., Saufi, S.M., An efficient conversion of waste feather keratinin to ecofriendly bioplastic film, Clean Technol Environ Policy, 2018, 20, 10, 2157-2167, https://doi. org/10.1007/s10098-018-1498-2.

19. Kumar, D., Babu, G., Krishnan, S., Study on mechanical \& thermal properties of PCL blended graphene biocomposites, Polimeros, 2019, 29, 2, https://doi.org/10.1590/0104-1428.05318.

20. Lee, K., Kaplan, D., Tissue Engineering I: Scaffold Systems for Tissue Engineering, Springer, Engineering Biomedical Engineering Advances in Biochemical Engineering/Biotechnology Tissue Engineering, 2006, Editors: Lee, Kyongbum, Kaplan, David.

21. Mano, J., Silva, G., Azevedo, H.S., Malafaya, P., Sousa, R., Silva, S.S., Boesel, L.F., Oliveira, J.M., Santos, T.C., Marques, A.P., Neves, N.M., Reis, R.L., Natural origin biodegradable systems in tissue engineering and regenerative medicine: present status and some moving trends, J R Soc Interface, 2007, 4, 17, 999-1030, https://doi. org/10.1098/rsif.2007.0220.

22. Malafaya, P.B., Silva, G.A., Reis, R.L., Naturalorigin polymers as carriers and scaffolds for biomolecules and cell delivery in tissue engineering applications, Adv Drug Deliv Rev, 2007, 59, 4-5, 207-233, https://doi. org/10.1016/j.addr.2007.03.012.

23. Curcio, M., Blanco-Fernandez, B., DiazGomez, L., Concheiro, A., Alvarez-Lorenzo, C., Hydrophobically modified keratin vesicles for GSH-responsive intracellular drug release, Bioconjugate Chem, 2015, 26, 9, 1900-1907, https://doi.org/10.1021/acs. bioconjchem.5b00289.

24. Pastar, I., Stojadinovic, O., Yin, N.C., Ramirez, H., Nusbaum, A.G., Sawaya, A., Patel, S.B., Khalid, L., Isseroff, R.R., Tomic-Canic, M., Epithelialization in wound healing: a comprehensive review, $A d v$ Wound Care, 2014, 3, 7, 445-464, https://doi. org/10.1089/wound.2013.0473.

25. Patrucco, A., Visai, L., Fassina, L., Magenes, G., Tonin, C., Keratin-based Matrices from Wool Fibers and Human Hair, Materials for Biomedical Engineering, Elsevier, 2019, 375-403, https:// doi.org/10.1016/B978-0-12-816872-1.00013-3.

26. Kim, S.Y., Park, B.J., Lee, Y., Park, N.J., Park, K.M., Hwang, Y.-S., Park, K.D., Human hair keratin-based hydrogels as dynamic matrices for facilitating wound healing, J Ind Eng Chem, 2019, 73, 142-151, https://doi.org/10.1016/j. jiec.2019.01.017.

27. Gao, F., Li, W., Deng, J., Kan, J., Guo, T., Wang, B., Hao, S., Recombinant human hair keratin nanoparticles accelerate dermal wound healing, ACS Appl Mater Interfaces, 2019, https://doi. org/10.1021/acsami.9b01725.

28. Rahmani Del Bakhshayesh, A., Annabi, N., Khalilov, R., Akbarzadeh, A., Samiei, M., Alizadeh, E., Alizadeh-Ghodsi, M., Davaran, S., 
Montaseri, A., Recent advances on biomedical applications of scaffolds in wound healing and dermal tissue engineering, Artif Cells Nanomed Biotechnol, 2018, 46, 4, 691-705, https://doi.or g/10.1080/21691401.2017.1349778.

29. Shavandi, A., Silva, T.H., Bekhit, A.A., Bekhit, A.E.-D.A., Keratin: dissolution, extraction and biomedical application, Biomater Sci, 2017, 5, 9, 1699-1735, https://doi.org/10.1039/ C7BM00411G.

30. Vasconcelos, A., Freddi, G., Cavaco-Paulo, A., Biodegradable materials based on silk fibroin and keratin, Biomacromolecules, 2008, 9, 4, 1299-1305, https://doi.org/10.1021/ bm7012789.

31. Fujii, T., Ide, Y., Preparation of translucent and flexible human hair protein films and their properties, Biol Pharm Bull, 2004, 27, 9, 14331436, https://doi.org/10.1248/bpb.27.1433.

32. Lv, X., Li, Z., Chen, S., Xie, M., Huang, J., Peng, X., Yang, R., Wang, H., Xu, Y., Feng, C., Structural and functional evaluation of oxygenating keratin/ silk fibroin scaffold and initial assessment of their potential for urethral tissue engineering, Biomaterials, 2016, 84, 99-110, https://doi. org/10.1016/j.biomaterials.2016.01.032.

33. Feroz, S., Muhammad, N., Ratnayake, J., Dias, G., Keratin-based materials for biomedical applications, Bioact Mater, 2020, 5, 496-509, https://doi.org/10.1016/j. bioactmat.2020.04.007.

34. Simion, D., Gaidău, C., Chirilă, C., Berechet, M.D., Niculescu, M., Epure, D.G., New structured emulsions based on renewable resources generated by leather and fur industry, with application in agriculture, ICAMS 20187th International Conference on Advanced Materials and Systems, 2018, 205-210, https:// doi.org/10.24264/icams-2018.II.5.

35. Gaidau, C., Epure, D.G., Enascuta, C.E., Carsote, C., Proietti, N., Chen, W., Gu, H., Wool keratin total solubilisation for recovery and reintegration-an ecological approach, J Clean Prod, 2019, 236, 117586, https://doi. org/10.1016/j.jclepro.2019.07.061.

36. Zhang, J., Li, Y., Li, J., Zhao, Z., Liu, X., Li, Z., Han, Y., Hu, J., Chen, A., Isolation and characterization of biofunctional keratin particles extracted from wool wastes, Powder Technol, 2013, 246, 356-362, https://doi.org/10.1016/j. powtec.2013.05.037.

37. Khosa, M.A., Ullah, A., In-situ modification, regeneration, and application of keratin biopolymer for arsenic removal, J Hazard Mater,
2014, 278, 360-371, https://doi.org/10.1016/j. jhazmat.2014.06.023.

38. Hill, P., Brantley, H., Van Dyke, M., Some properties of keratin biomaterials: Kerateines, Biomaterials, 2010, 31, 585-593, https://doi. org/10.1016/j.biomaterials.2009.09.076.

39. Pavia, D.L., Lampman, G.M., Kriz, G.S., Vyvyan, J.A., Introduction to Spectroscopy, Cengage Learn, 4th ed, Belmont, 2008, 752.

40. Mohanty, A.K., Misra, M., Drzal, L.T., Natural Fibers, Biopolymers, and Biocomposites, 2005, CRC press, https://doi. org/10.1201/9780203508206.

41. Kakkar, P., Balaraman, M., Shanmugam, G., Transient structures of keratins from hoof and horn influence their self association and supramolecular assemblies, Int J Biol Macromol, 2016, 93, 172-178, https://doi.org/10.1016/j. ijbiomac.2016.08.077.

42. Chen, Y.C., Tou, J., Jaczynski, J., Amino acid and mineral composition of protein and other components and their recovery yields from whole Antarctic krill (Euphausia superba) using isoelectric solubilization/precipitation, J Food Sci, 2009, 74, 2, H31-H39, https://doi. org/10.1111/j.1750-3841.2008.01026.x.

43. Staron, P., Banach, M., Kowalski, Z., Staron, A., Hydrolysis of keratin materials derived from poultry industry, Proceedings of ECOpole, 2014, 443-448.

44. Krejci, O., Mokrejs, P., Sukop, S., Preparation and characterization of keratin hydrolysates, Mathematical Methods and Techniques in Engineering and Environmental Science, 2011, 308-311.

45. Ji, Y., Chen, J., Lv, J., Li, Z., Xing, L., Ding, S., Extraction of keratin with ionic liquids from poultry feather, Sep Purif Technol, 2014, 132, 577-583, https://doi.org/10.1016/j. seppur.2014.05.049.

46. Ha, S.W., Tonelli, A.E., Hudson, S.M., Structural studies of Bombyx mori silk fibroin during regeneration from solutions and wet fiber spinning, Biomacromolecules, 2005, 6, 1722, https://doi.org/10.1021/bm050010y.

(C) 2020 by the author(s). Published by INCDTPICPI, Bucharest, RO. This is an open access article distributed under the terms and conditions of the Creative Commons Attribution license (http:// creativecommons.org/licenses/by/4.0/). 